$\begin{array}{ll}\text { Research Square } & \begin{array}{l}\text { Preprints are preliminary reports that have not undergone peer review. } \\ \text { They should not be considered conclusive, used to inform clinical practice, } \\ \text { or referenced by the media as validated information. }\end{array}\end{array}$

\title{
Combined effect of Drypetes gossweileri essential oil and organic acids on the inhibition of Bacillus spore germination using response surface methodology
}

Rodica-Mihaela Dinica ( $\square$ rodica.dinica@ugal.ro)

"Dunărea de Jos" University of Galati

Stève Olugu Voundi

University of Douala, University Institute of Technology, Université-Entreprises (PCUE), Laboratoire de Contrôle Qualité

Iuliana Lazar

University of Bucharest

Francine Tankeu Nzufo

University of Yaounde I

Dumitra Raducanu

Vasile Alecsandri University of Bacau

loan Viorel Rati

Vasile Alecsandri University of Bacau

Maximilienne Nyegue

University of Yaounde I

François-Xavier Etoa

University of Yaounde I

Research Article

Keywords:

Posted Date: February 15th, 2022

DOI: https://doi.org/10.21203/rs.3.rs-1288600/v1

License: (c) (1) This work is licensed under a Creative Commons Attribution 4.0 International License. Read Full License 


\section{Abstract}

This work assessed the combined effect of Drypetes gossweileri essential oil (EO) and three organic acids ( $\mathrm{Na}^{+}$benzoate, $\mathrm{Na}^{+}$lactate and Sorbic acid) on the inhibition of germination and growth of Bacillus spores. The test consisted of inoculating activated spores of each Bacillus species in 4 ml of nutrient broth under the combined effect of $D$. gossweileri EO $(0.62,5.31$ and $10 \mu \mathrm{g} / \mathrm{ml})$, each organic acid $(0.01,0.05$ and $0.1 \%)$ at different pH levels $(4.5,5.75$ and 7.0$)$ taken as independent variable. After incubating for 48 hours, the inhibition percentages of spores germination were used to generate the polynomial model: $Y$ $(\%)=\beta_{0}-\beta_{1} X_{1}+\beta_{2} X_{2}+\beta_{3} X_{3}+\beta_{1,1} X_{1}^{2}+\beta_{1,2} X_{1} X_{2}+\beta_{1,3} X_{1} X_{3}+\beta_{2,2} X^{2}{ }_{2}+\beta_{2,3} X_{2} X_{3}+\beta_{2,3} X_{3}{ }^{2}$. The ANOVA test was used to determine how significant ( $\mathrm{X}$ $0.05)$ of each factor, their interactions and the validity of the final models. The results showed that the determination coefficient $\left(R^{2}\right)$ and the adjusted coefficients ( $R^{2}$ adj) were generally close. For each bacterial species, all the models were significant $(p \otimes 0.05)$. For each organic acids, the interaction effect with $D$. gossweileri EO $\left(\mathrm{X}_{1} \mathrm{X}_{2}\right)$ was positive and significant $(\mathrm{p} \otimes 0.05)$ in at least one bacterial species out of the four tested. $\mathrm{Na}^{+}$lactate showed a more positive and significant $(\mathrm{p} \otimes 0.05)$ interactions with $\mathrm{EO}$, as observed on B. megaterium, B. subtilis and G. stearothermophilus spores with regression coefficients of $23.54 ; 15.83$ and 7.41 respectively. Decreasing the $\mathrm{pH}$ increases the sensitivity of the spores to $D$. gossweileri EO and organic acids. Indeed at pH 7.0 , no total inhibition of spore germination was obtained while at 5.75 , total inhibition of spore germination ( $100 \%$ inhibition) was observed for $B$. cereus and $G$. stearothermophilus for $\mathrm{Na}^{+}$benzoate; $G$. stearothermophilus for $\mathrm{Na}+$ lactate and B. cereus, B. megaterium and B. subtilis for Sorbic acid. From these results, it was concluded that $D$. gossweileri EO combined with organic acid might be a valuable tool for bacterial spores control in the food industries.

\section{Introduction}

In many countries, food microbial spoilage is one of the major concerns since it is the cause of significant food losses. In addition, contaminated foods usually lead to food poisoning resulting in human death [1-2]. This remains one of the major health problems in developing countries where each year, around two million people die from diarrhea resulting from food poisoning [3].

Among the main food microbial spoilage, the control of spore-forming bacteria in general and that of Bacillus species in particular, represents one of the major challenges for industries. In fact, Bacillus are characterized by powerful food spoilage with some species able to grow at refrigeration temperatures ( 5 to $7^{\circ}$ C), as well as at pH below 4.5. In addition, Bacillus can form spores characterized by a high resistance to many types of food sterilization processes and the germination of spores of certain Bacillus remains a major health concern [4-7]. It is the case of Bacillus cereus which owing to its sporulated form, generally survive to acidic $\mathrm{pH}$ of the stomach and can reach the small intestine which is a suitable site for the production of hemolysin and cytotoxin responsible of diarrhea $[7,8]$.

To inactivate bacterial spores in food industries, heat treatments (sometimes combined with high pressure) at temperatures above $100^{\circ} \mathrm{C}$ remain the most widely used methods which generally lead to degradation of the nutritional and sensory properties of food [9]. Therefore, some industries still used pasteurization which unfortunately doesn't destroy spores, but sometimes rather triggers their germination [10]. To limit these failures, an alternative means consists of adding the organic acids to food to inhibit subsequent germination of spores. To date, organic acids and their salts are attractive options due to their various positive attributes including broad-spectrum antimicrobial activity, heat stability and no effect on color or flavor [11-13]. Sorbate and benzoate are affirmed as Generally Recognized as Safe (GRAS) in some countries, with authorized concentration of $0.1 \%$ for sodium benzoate in the USA, whereas up to 0.15 to $0.25 \%$ in most other countries [11]. However, antibacterial effects of organic acids are generally efficient at low pH (usually below 5 ) which limits their use in some foods. In addition, the field of food preservation is now facing the problem of some acidotolerant Bacillus (Bacillus sporothermodurans and Alicyclobacillus acidoterrestris) [4].

It is therefore obvious that, the search for sterilization processes that inhibit or inactivate bacterial spores remain an important need for optimizing the health qualities of foods. One of the interesting strategies is to study the effects of natural substances with antimicrobial and anti-sporogenic activities. Thus, Drypetess gossweileri (Euphorbiaceae) is a plant found in tropical Africa, mainly in the forests of Cameroon, Gabon, Democratic Republic of Congo, Central African Republic and Ghana. The roots and bark of D. gossweileri are traditionally used for therapeutic purposes by certain Cameroonian ethnic groups. A decoction or maceration of the bark is commonly drunk as a purgative to expel intestinal worms and treat diarrhea. Ngono [14] revealed the antibacterial effect of D. gossweileri (collected in the Central Region of Cameroon) essential oil (EO) on a wide range of Gram-negative bacteria responsible of food poisoning. Concerning inhibition of germination of spores, in ours previous study, out of the nine EO of medicinal plants tested, EO of $D$. gossweileri was the most active, with inhibitory effect observed on B. cereus, B. subtilis, B. megaterium and G. stearothermophilus [15]. In addition, D. gossweileri EO used from $0.02 \mathrm{mg} / \mathrm{ml}$ inhibited germination of Bacillus spores in two model food systems (orange juice and milk) [16]. However, at the aforementioned concentration, $D$. gossweileri EO lead to a change of odor and taste in foodstuff and was appreciated as undesirable by the panel [16]. Based on these results, the use of $D$. gosweilleri EO as food preservative needs a reduced concentration to avoid the deterioration of the sensory properties of food suggesting its use in combination with other food preservative. To date, the combination of preservative methods represents a promising future in the field of food preservation. To the best of knowledge, no work has so far evaluated the combined effects of EO in general and D. gossweileri EO in particular with organic acids. Therefore, in this work, we assessed the combined effect of Drypetes gossweileri $\mathrm{EO}$ and three organic acids ( $\mathrm{Na}^{+}$benzoate, $\mathrm{Na}^{+}$lactate and Sorbic acid) on inhibition of germination and growth of four Bacillus spores using response surface methodology.

\section{Material And Methods \\ D. gossweileri essential oil}

The plant used in this study for essential oil extraction is Drypetes gossweileri S. Moore of Euphorbiaceae family. The plant material samples (stem barks) were harvested at Ntongo, a locality of Center Region of Cameroon in June 2011. The collection as well as the identification of the plant were done under the 
supervision of Dr Rosette Christelle NDJIB, Research Officer of the Laboratory of Botany of the Center for Research on Medicinal Plants and Traditional Medicine of Cameroonian Ministry of Scientific Research and Innovative which is the highest institute in charge of studies on medicinal plants at the national level. The procedure of harvest and identification were carried out according to the legislation in force

The essential oil (EO) extraction was done by hydro-distillation using a Clevenger-type apparatus and analyzed by Gas Chromatography-Flame lonization Detection (GC-FID) [15]. The essential oil was composed mainly of benzyl isothiocyanate (86.7 \%) a glucosynolate derivative compound [15].

\section{Organic acid}

$\mathrm{Na}^{+}$Benzoate, $\mathrm{Na}^{+}$Lactate and Sorbic acid are organic acids used in industries as food preservatives with an inhibiting effect on the germination of bacterial spores [17]. In this study, these three organic acids were evaluated for their inhibitory effect on spore germination in combination with $D$. gossweileri EO. All the three organic acids were purchased from Sigma Aldrich.

\section{Bacterial strains and production of spores}

Bacillus cereus T, Bacillus subtilis NCTC 3610 and Bacillus megaterium 8174 were obtained from the Microbiology Laboratory of the Institute of Food Research of Reading, UK. Geobacillus stearothrmophilus was supplied by the Institut Appert de Paris. Spores production was carried as described by Bayoï et al. [18]. Vegetative cells of each strain grown for $12 \mathrm{~h}$ on tryptycase soy broth were spread upon sporulation agar medium. The plates were incubated for 5 days at optimal growth temperature of each species $\left(35^{\circ} \mathrm{C}\right.$ for Bacillus species and at $63^{\circ} \mathrm{C}$ for G. stearothrmophilus) to obtain spores. The spores were collected with glass spatula, suspended in distilled water and purified by seven centrifugation cycles at $3000 \mathrm{~g}$ for $15 \mathrm{~min}$. The pellet corresponding to purified spores were then suspended in distilled cold water and stored at $4{ }^{\circ} \mathrm{C}$ for 3 months to ensure spore's stability before use [18].

\section{Heat-activation of spores}

Before use, each preparation of spore was heat-activated using the standard method. The activations were performed on $4 \mathrm{ml}$ of each preparation of spores adjusted at $10^{8}$ spores $/ \mathrm{ml}$ contained in test tubes. This consisted to maintain each suspension in oil bath at $80^{\circ} \mathrm{C}$ for 10 min, followed afterwards by sudden cooling using ice bath for $10 \mathrm{~min}[16,18]$.

\section{Combined effect of $D$. gossweileri EO and organic acids on inhibition of spore germination and growth}

Box-Behnken optimized surface response method was used to assess the combined effects of $D$. gossweileri EO and organic acid on inhibition of spore germination and growth. This method simultaneously studied the inhibition of spore germination and growth response (Y), under the variation of $D$. gossweileri EO concentration $\left(\mathrm{X}_{1}\right)$, each organic acid $\left(\mathrm{X}_{2}\right)$ and $\mathrm{pH}\left(\mathrm{X}_{3}\right)$ taken as factors. A mathematical analysis of the responses obtained from the combinations of factors allowed to study the significant effect of each independent variable and their interactions. A mathematical model describing the relationship between the inhibitions of spore germination $(Y)$ under the concentration of EO, organic acid and $\mathrm{pH}$ of medium were generated using uncoded values of factors. The factors were used each at three modality levels as shown in Table 1.

\section{Experimental design}

The analyses consisted to inoculate activated spores of each Bacillus (at final concentration of $10^{6}$ spores / $\mathrm{ml}$ ) in $4 \mathrm{ml}$ of nutrient broth (supplemented with $0.2 \%$ tween 80 ) under the variation of each independent variable $\left(X_{1}, X_{2}\right.$ and $\left.X_{3}\right)$ tested at one modality levels (Table 1). The experiment was carried out using design generated by MINITAB 16 software (Table 2), made by 12 combinations done 30 times with 6 repetitions at the central point.

After inoculation, the samples were incubated for 48 hours at optimum growth temperature for each species $\left(35^{\circ} \mathrm{C}\right.$ for $B$. cereus, $B$. subtilis and $B$ megaterium and $63^{\circ} \mathrm{C}$ for $\mathrm{G}$. stearothermophilus). The values of optical density (OD) (indicator of spore germination and growth) were determined for each condition using a Cary 100 UV-Vis-NIR spectrophotometer (Agilent Technologies, Les Ulis, France) at $620 \mathrm{~nm}$ (maximum absorption of the spores). The preparations of control spores containing neither EO nor organic acid, at pH 7, were carried out under the same conditions. $Y$ responses representing percentages of germination inhibition and spore growth were calculated using the formula below [17]; with $\mathrm{Y}(\%)=\operatorname{Inhibition}$ of spores germination and growth $(\%)$; $\mathrm{OD}_{\mathrm{c} 48 \mathrm{~h}}=$ Optical density of controls spores after 48 hours; $\mathrm{OD}_{\mathrm{cOh}}=$ Initial optical density of controls spores; $\mathrm{OD}_{\mathrm{t} 48 \mathrm{~h}}=$ Optical density of tested spores after 48 hours; $\mathrm{OD}_{\mathrm{toh}}=$ Initial optical density of tested spores.

$$
\begin{aligned}
& {\left[\left(O D_{c 48 h}-O D_{c 0 h}\right)-\left(O D_{t} 48 h-O D_{t ~} 0 h\right)\right]} \\
& \mathrm{Y}(\%)=\longrightarrow \times 100 \\
& \left(O D_{c} 48 h-O D_{c 0 h}\right)
\end{aligned}
$$




\section{Mathematical model and statistical analyses}

The responses $(Y)$ calculated were expressed in a polynomial mathematical model describing the relationship between the inhibitions of spore germination (\%) as a function of the $\mathrm{pH}$, the concentration of $\mathrm{EO}$ and that of each organic acid according to the equation $Y(\%)=\beta_{0}-\beta_{1} X_{1}+\beta_{2} X_{2}+\beta_{3} X_{3}+\beta_{1,1} X_{1}^{2}+\beta_{1,2}$ $X_{1} X_{2}+\beta_{1,3} X_{1} X_{3}+\beta_{2,2} X^{2}{ }_{2}+\beta_{2,3} X_{2} X_{3}+\beta_{2,3} X_{3}{ }^{2}$, where $Y(\%)$ represents the predicted response; $X_{1} ; X_{2}$ and $X_{3}$ are the uncoded values of $D$. gossweileri EO concentrations, organic acid concentrations and $\mathrm{pH}$ respectively; $\mathrm{X}_{1} \mathrm{X}_{2}, \mathrm{X}_{1} \mathrm{X}_{3}$ and $\mathrm{X}_{2} \mathrm{X}_{3}$ represent the interactions between EO - organic acid; EO - $\mathrm{pH}$ and organic acid-pH; $\mathrm{X}_{1}{ }^{2}, \mathrm{X}^{2}{ }_{2}$ and $\mathrm{X}_{3}{ }^{2}$ are the quadratic parameters and $\beta_{0} \ldots \beta_{2,3}$ represent the constants and the regression coefficients of the independent variables, interactions and quadratics. The ANOVA tests was carried out using STATGRAPHICS Plus 5.1 software which allowed us to determine the significant $(p \otimes 0.05)$ of each factors, their interactions, the confidence intervals $\left(R^{2}\right.$ and adjusted $\left.R^{2}\right)$ and the validity of the final models.

\section{Results}

The percentages inhibition of spore germination and growth of the four bacterial species under the combined effect of $D$. gossweileri EO and organic acid ( $\mathrm{Na}^{+}$Benzoate, $\mathrm{Na}+$ Lactate or Sorbic acid) are summarized in the Tables 3, 4 and 5 respectively. From these values, mathematical models expressing the percentage inhibition of germination of each bacterial specie under the variation of $\mathrm{pH}, \mathrm{EO}$ concentrations and those of each organic acid were determined.

From the values of percentage inhibition germination and spore growth recorded, mathematical models expressing the percentages inhibition of germination of each bacterial specie under the variation of $\mathrm{pH}$, EO concentrations and those of each organic acid were determined. The analyses of different models as well as the analyses of the regression coefficients variances are represented in the Table 6, 7 and 8. As observed in Table 6 for the combined $D$. gossweileri EO and $\mathrm{Na}^{+}$Benzoate, the determination coefficients $\mathrm{R}^{2}$ (79.56 to $94.18 \%$ ) and the adjusted coefficients $\mathrm{R}^{2}$ adj (70.37 to $\left.91.56 \%\right)$ obtained with the models for the four bacterial species are close to $100 \%$. Similar results were obtained with the effects of $D$. gossweileri EO combined with $\mathrm{Na}^{+}$Lactate were the determination coefficients $R^{2}$ as well as the adjusted coefficients ( $R^{2}$ adj) ranging from 87.62 to $92.04 \%$ and from 82.05 to $88.47 \%$ respectively were close to $100 \%$. For the models obtained with combined D. gossweileri EO- sorbic acid, it was observed that the coefficients of determination $\mathrm{R}^{2}$ ranged from 75.26 to $95.25 \%$ and the adjusted coefficients ( $R^{2}$ adj) ranged from 64.12 to $93.11 \%$ were also close to $100 \%$.

In addition, for all the organic acids, all the proposed models were highly significant with $P$-value $=0.00($ Tables 6,7 and 8$)$ showing that all the models reflected the existence of excellent relationship between the percentage inhibition of germination of spore ( $Y$ ) and the different factors (concentration of essential oil $\left(X_{1}\right)$, the concentration of each organic acid $\left(X_{2}\right)$ and the $\mathrm{pH}\left(\mathrm{X}_{3}\right)$ ). In addition to the significance of the different models, the analyses of variance realized for each model allowed us to study the significance of each factor, their interaction as well as the quadratic parameters. For the models combining the EO of $D$. gossweileri and $\mathrm{Na}^{+}$Benzoate, the results summarized in Table 6 shows that, for $B$. cereus, both the effects of the independent variables $\left(X_{1} ; X_{2} ; X_{3}\right)$ and the effects of the three quadratic parameters $\left(X_{1}{ }^{2} ; x_{2}{ }^{2} ; X_{3}{ }^{2}\right)$ are significant $(p<0.05)$. Similarly, for $B$. megaterium, the effects of the independent variables $\left(X_{1} ; X_{2} ; X_{3}\right)$ and the effects of two quadratic parameters $\left(X_{1}^{2} ; X_{2}^{2}\right)$ are significant $(p<0.05)$. Concerning the model of $B$. subtilis, the effects of variables $\left(X_{1} ; X_{2}\right.$; $\left.\mathrm{X}_{3}\right)$, the interactions $\left(\mathrm{X}_{1} \mathrm{X}_{2} ; \mathrm{X}_{1} \mathrm{X}_{3} ; \mathrm{X}_{2} \mathrm{X}_{3}\right)$ and the quadratic parameters $\left(\mathrm{X}_{1}^{2} ; \mathrm{X}_{2}^{2} ; \mathrm{X}_{3}^{2}\right)$ were significant $(\mathrm{p}<0.05)$ while for the $G$. stearothermophilus only the independent variables $\left(X_{1} ; X_{2} ; X_{3}\right)$ and the quadratic parameter $\left(X_{2}^{2}\right)$ significantly affected the inhibition of spore germination $(p<0.05)$. For each bacterial species, a reduced model (presented in Table 6 ) gives a better representation of the percentages of inhibition of germination and spore growth under the effect of different variables was given taking into account only those that are significant. From the reduced equations, the response contour curves representing the percentage inhibition of spore germination under combined $D$. gossweileri $\mathrm{EO}$ and $\mathrm{Na}+$ Benzoate at pH 7 and 5.75 were plotted and represented in Fig. $1 \mathrm{a}$ to $1 \mathrm{~d}$ respectively for $B$. cereus, B. megaterium, B. subtilis and G. stearothermophilus. From the analysis of Fig. 1, it appears that at $\mathrm{pH} 7$, no total inhibition (100\% inhibition) of spore germination was observed with all bacterial species. However, the inhibition percentage of spores germination and growth vary from 20 to $70 \%$ for $B$. cereus. Similarly, for $B$. megaterium the percentages of inhibition ranged from $<10$ to $70 \%$, whereas for $B$. subtilis and $G$. stearothermophilus, the values range from $<10$ to $90 \%$ and 20 to $90 \%$ respectively. The spores of $B$. cereus and G. stearothermophilus were the most sensitive as they exhibit the most significant inhibitions with percentages ranging from 60 to $70 \%$ and 60 to $90 \%$ respectively at high concentrations of $\mathrm{EO}$ and $\mathrm{Na}^{+}$benzoate.

Decreasing the $\mathrm{pH}$ of the medium increases the sensitivity of the spores to the combined effect of $\mathrm{EO}-\mathrm{Na}^{+}$Benzoate. Indeed, at pH 5.75 total inhibitions of spore germination (100\% inhibition) were observed for B. cereus and G. stearothermophilus while for B. megaterium and B. subtilis higher inhibitions between 80 to $90 \%$ were obtained.

Concerning the combined effect of $D$. gossweileri EO and $\mathrm{Na}^{+}$Lactate (Table 7), from the models obtained, the results of the analysis of the variance showed that for $B$. cereus, only the effects of two independent variables $\left(X_{1}\right.$ and $\left.X_{3}\right)$ and the quadratic parameters $\left(X_{1}{ }^{2} ; X_{2}{ }^{2} ; X_{3}{ }^{2}\right)$ significantly affected the spore germination $(p<0.05)$. In contrast, for $B$. megaterium, the effects of two independent variables $\left(X_{1}\right.$ and $\left.X_{3}\right)$, the interaction $\left(X_{1} X_{2}\right)$ and the two quadratic parameters $\left(X_{2}{ }^{2} ; X_{3}{ }^{2}\right)$ were significant $(p<0.05)$. Concerning $B$. subtilis, only the effects of the independent variables $\left(X_{1} ; X_{2} ; X_{3}\right)$, the interaction $\left(X_{1} X_{2}\right)$ and of the quadratic parameters $\left(X_{1}{ }^{2} ; X_{2}{ }^{2} ; X_{3}{ }^{2}\right)$ were significant $(p<0.05)$. Whereas for $G$. stearothermophilus, the effects of two independent variables $\left(X_{1} ; X_{3}\right)$, the interaction $\left(X_{1} X_{2}\right)$ and the quadratic parameter $\left(X_{3}^{2}\right)$ were significant $(p<0.05)$. For each bacterial species, a reduced model (presented in Table 7$)$ gives a better representation of the percentages of inhibition of germination and spore growth as a function of the significant parameters was contructed.

From the reduced equations, the response contour curves expressing the percentages of inhibition of germination and spore growth under the combined effect of EO and $\mathrm{Na}^{+}$Lactate at $\mathrm{pH} 7$ and 5.75 were plotted and shown in Fig. 2a-2d below respectively for B. cereus, B. megaterium, B. subtilis and G. stearothermophilus. From the analysis of Fig. 2, it appears that at $\mathrm{pH} 7$, no complete inhibition of spore germination was observed in all bacterial species. The inhibition percentages of spores germination and growth varied from 10 to $70 \%$ for $B$. cereus, from $<10$ to $90 \%$ for $B$. megaterium, from < 10 to $60 \%$ for $B$. 
subtilis and 10 to $60 \%$ for $G$. stearothermophilus. However, the highest percentages of inhibitions ranged from 70 to $90 \%$ and can be observed for $B$. megaterium at the highest concentrations of $\mathrm{EO}$ and $\mathrm{Na}^{+}$Lactate. B. subtilis and $\mathrm{G}$. stearothermophilus appear to be the most resistant as they do not exhibit inhibition percentages greater than $60 \%$ even at the highest concentrations of EO and organic acid.

At pH 5.75 the inhibitory effect of germination and spore growth increases strongly in most bacterial species. In fact, the germination inhibition percentages of B. cereus now varied from 40 to $90 \%$, while those of $B$. megaterium varied from 20 to $100 \%$. The greatest improvement inhibitory effect was observed with $G$. stearothermophilus where a total germination inhibition (100\%) of the spores was obtained at lower concentrations of $\mathrm{EO}^{2}$ and $\mathrm{Na}^{+}$lactate. However, the $B$. subtilis compared to the others appeared once again more resistant, with no inhibition greater than $60 \%$.

The inhibition of germination and spore growth of the four bacterial species under the combined effect of $D$. gossweileri EO and Sorbic acid were also assessed and the results obtained are presented in Tables 4 below. Mathematical models representing the inhibition percentages of germination and spore growth under the values of $\mathrm{pH}, \mathrm{EO}$ concentrations and those of sorbate were determined. The variances analyses of the regression coefficients and the significance of the factors represented in Table 8 shows that for $B$. cereus, the effects of the two independent variables $\left(X_{1}\right.$ and $\left.X_{3}\right)$, the interaction $\left(X_{1} X_{3}\right)$ and the quadratic parameters $\left(X_{1}{ }^{2} ; X_{2}{ }^{2} ; X_{3}{ }^{2}\right)$ were significant $(p<0.05)$. For $B$. megaterium, the effects of the independent variable $\left(X_{3}\right)$, the interaction $\left(X_{1} X_{3}\right)$ and two quadratic parameters $\left(X_{1}{ }^{2} ; X_{3}{ }^{2}\right)$ where significant $(p<0.05)$. For $B$. subtilis, the effects of the independent variables $\left(X_{1} ; X_{2} ; X_{3}\right)$, the interactions $\left(X_{1} X_{2}\right.$ and $\left.X_{2} X_{3}\right)$ and the quadratic parameter $\left(X_{2}{ }^{2}\right)$ were significant $(p<0.05)$. For $G$. stearothermophilus, the effects of the independent variables $\left(X_{1} ; X_{2} ; X_{3}\right)$ and for the two quadratic parameters $\left(\mathrm{X}_{2}^{2} ; \mathrm{X}_{3}^{2}\right)$ were significant $(\mathrm{p}<0.05)$.

As for the case of lactate, a reduced model was deduced for each bacterial species from the general model for the combined effect of EO of $D$. gossweileri and sorbic acid and the resulting equations presented in Table 8. From the above equations, the response contour curves representing the percentages of inhibition of germination and spore growth under the combined effect of EO, sorbic acid and pH at 7 and 5.75 were plotted and presented in Fig. 3a-3d below, respectively for $B$. cereus, $B$. megaterium, $B$. subtilis and $G$. stearothermophilus. The analysis of Fig. 3 clearly showed that at $\mathrm{pH} 7.0$, the spores of $B$. megaterium and $G$. stearothermophilus are the most sensitive to the combined effects of EO and sorbic acid with the percentages of inhibition ranging from 10 to $70 \%$. Conversely, the less sensitive were B. cereus and B. subtilis with inhibition percentages ranging from $<10$ to $50 \%$.

In contrast at $\mathrm{pH} 5.75$, both the inhibiting effects of spores germination and growth are greatly increased for all the bacterial species. Hence, a total inhibition (100\% inhibition) was observed for B. cereus, B. megaterium and B. subtilis. However, in general, the inhibitions of spore germination ranged from 50 to $100 \%$ for B. cereus, 80 to $100 \%$ for B. megaterium, 10 to $90 \%$ for B. subtilis and 40 to $90 \%$ for G. stearothermophilus.

\section{Discussion}

The combined effects of $D$. gossweileri $\mathrm{EO}$ and $\mathrm{Na}^{+}$Benzoate, $\mathrm{Na}^{+}$Lactate and Sorbic acid were investigated on the germination and growth of spores of four Bacillus species. The optimized Box-Behnken Response Surfaces Method was used to establish for each Bacillus specie, a linear relationship between the inhibition percentages of germination and spore growth according to $\mathrm{pH}$, EO concentration and that of each organic acid. All the models obtained presented the coefficients of determination $\left(R^{2}\right)$ and the corresponding adjusted coefficients $\left(R^{2}\right.$ adj) generally close indicating a high relationship between the obtained experimental values and the adjusted values (adjusted values by the mathematical models). Furthermore, the coefficients of determination were greater than $70 \%$, suggesting that in general all the models obtained significantly explain the variations of the percentages inhibition of the germination and spores growth under the combined factors. For all the proposed models, the $p$-values $(p=0.00)$ ascertain that there is a very good linear relationship between the inhibition of germination and spore growth and the variables. Moreover, these observations confirm the suitability of the Box-Behnken Surface Response method for this study.

In addition to goodness-of-fit and the adequacy of the models, the optimization method also allowed to study the nature (positive or negative) and the significance of the interaction between the factors through the analyses of variances. According to the results, for each of the three organic acids evaluated, the effects of the $D$. gossweileri EO and organic acids interaction $\left(X_{1} X_{2}\right)$ were positive and significant $(p \otimes 0.05)$ in at least one bacterial species out of the four tested. For $\mathrm{Na}^{+}$Benzoate, the interaction with $\mathrm{EO}$ was positive and significant on $B$. subtilis spores with a regression coefficient of 19.41 . Regarding $\mathrm{Na}^{+}$ Lactate, significant interactions with EO were found for the inhibition of $B$. megaterium, $B$. subtilis and $G$. stearothermophilus with the respective regression coefficients of $23.54 ; 15.83$ and 7.41. As for the combination with Sorbic acid, the positive interaction of $D$. gossweileri EO and organic acid $\left(X_{1} X_{2}\right)$ was obtained on the inhibition of the germination of $B$. cereus, with a regression coefficient of 11.63 . These results show that in at least one out to four bacterial species, the presence of $D$. gossweileri EO increases the inhibiting effect on germination and growth of spores by organic acid and vice versa

Many studies have been done on organic acids regarding their sporocidal or sporostatic effect on bacterial spores. Indeed, Sorbic acid at $3 \mathrm{mM}$ at pH 5.5 completely inhibited the germination of B. cereus ATCC 14579, whereas sodium Benzoate at 500 to 2000 ppm completely inhibits the germination of Bacillus acidoterrestris with sporostatic effect [19]. Similarly, $\mathrm{Ca}^{2+}, \mathrm{Na}^{+}$, and $\mathrm{K}^{+}$Lactate at concentrations $\geq 3.0 \%$ are used to inhibit the germination of Clostridium perfringens in pork during storage at low temperature [20]. Two mechanisms of action have been proposed for these effects. Indeed, in their protonated forms, organic acids can easily diffuse through the spore envelopes and dissociate in the core; this leads to a strong acidification of the core which is responsible for enzyme dysfunction [21]. Besides, organic acids can accumulate in the inner membrane of the spore leading to interactions with its function and blocking the spore outgrowth [22 - 23].

Concerning EOs, they have bacteriostatic or bactericidal effect and major compounds are generally responsible for this antimicrobial effect, although a synergistic effect of minor compounds is often mentioned [24]. However, the mechanism of action of EO on the inactivation of bacterial spores remains poorly understood. Conversely, their effects on vegetative growth are usually due to structural and functional dysfunction of the bacterial membrane and cytoplasm. 
The EO of $D$. gossweileri used is mainly composed of benzyl isothiocyanate. It is known that isothiocyanate derivatives are strongly antibacterial due to their $\mathrm{R}-\mathrm{N}=\mathrm{C}=\mathrm{S}$ groups. The central highly electrophilic carbon atom can rapidly react with oxygen, sulphide and nitrogen in nucleophilic centers leading to the formation of carbamate, thiocarbamate and thiourea derivatives which are toxic to cells. Isothiocyanates can also cleave disulfide bonds of proteins and attack free amino acids (arginine) through oxidative reactions. Besides, an inhibition effect on some cell enzymes is also suggested [25]. Some of these mechanisms are found to be similar or complementary to that of organic acids and probably explains the existence of positive interactions observed between D. gossweileri $\mathrm{EO}$ and the organic acids used in combination.

The results obtained in this work also showed that a decrease of the $\mathrm{pH}$ increases the effect of $\mathrm{EO}$ and organic acid combinations on the inhibition of spore germination. In general, the susceptibility of bacteria to antimicrobial agents increases with the decrease of $\mathrm{pH}$. The more the $\mathrm{pH}$ decreases, the more the hydrophobicity of antimicrobial compounds (EO and organic acids) increases; this contributes to their good diffusion and to their strong accumulation in the spore envelopes and core, the site of location of germination receptors [26].

\section{Conclusion}

The results of this study confirm synergistic effect of combined EO of D. gossweileri and three organic acids on the inhibition of spore germination and growth of four Bacillus species. This synergistic effect is justified by the positive interaction of combined $D$. gossweileri essential oil and each organic acid on at least one Bacillus species. Among the three organic acids tested, $\mathrm{Na}^{+}$Lactate showed the most positive and significant $(\mathrm{p} \otimes 0.05)$ interaction with EO observed on $B$. megaterium, $B$. subtilis and G. stearothermophilus with the regression coefficients of $23.54 ; 15.83$ and 7.41 respectively. For $\mathrm{Na}^{+} \mathrm{Benzoate}$ and Sorbic acid, a positive and significant interaction effect with $D$. gossweileri EO was observed on $B$. subtilis and $B$. cereus with regression coefficients of 19.41 and 11.63 respectively. Decreasing the $\mathrm{pH}$ increases the sensitivity of the spores to $D$. gossweileri EO and organic acids. Indeed, at pH 7.0 no total inhibition of spores was observed under the combined $D$. gossweileri $\mathrm{EO}$ and each organic acid. But, at $\mathrm{pH} 5.75$, total inhibition of spore germination (100\% inhibition) was observed for $B$. cereus and G. stearothermophilus for $\mathrm{Na}^{+}$Benzoate, G. stearothermophilus for $\mathrm{Na}^{+}$Lactate and B. cereus, B. megaterium and B. subtilis spores for Sorbic acid.

\section{Declarations}

\section{Acknowledgements}

We are grateful to the University Institute of Technology, Plate Forme de Coopération Université-Entreprises (PCUE), Laboratoire de Contrôle Qualité of the University of Douala, the University of Yaounde I, the Vasile Alecsandri University of Bacau and The "Dunărea de Jos" University of Galati for laboratory facilities. We thank also the Microbiology Laboratory of Institute of Food Research of Reading and the Institut Appert of Paris for providing us with bacterial spore strains.

\section{Author contributions}

I.L., F.-X.E. and R.-M.D. conceived the study, participated in its design and coordination. S.O.V., I.V.R. and D.R. performed experimentation. S.O.V. and F.T.N. carried out statistical analysis; S.O.V. and M.N. wrote and edited the manuscript. All authors reviewed and approved the final manuscript.

\section{Availability of data and materials}

Not applicable

\section{Additional information}

\section{Competing interests}

The author(s) declare no competing interests.

\section{Funding}

This research was funded by the the Vasile Alecsandri University of Bacau, the Agence Universitaire de la Francophonie (AUF) and The "Dunărea de Jos" University of Galati under the fellowship "Ecole Doctorale Inter Régionale en Biotechnologie Végétale et Agroalimentaire"

\section{References}

1. Kunwar, C R., Singh MH, Mangla, M. V. \& Hiremath, M. R. Outbreak investigation: Salmonella food poisoning. Medical Journal Armed Forces India 69, 388391 (2013).

2. Ababio, P. F. \& Lovatt, P. A. Review on food safety and food hygiene studies in Ghana. Food Control 47, 92 - 97 (2015).

3. Fukuda, K. Food safety in a globalized world. Bulletin of the World Health Organization 93 (4), 212 - 212 (2015). 
4. Lucasa, R. et al. Application of the broad-spectrum bacteriocin enterocin AS-48 to inhibit Bacillus coagulans in canned fruit and vegetable foods. Food and Chemical Toxicology 44 (10), 1774 -1781 (2006).

5. Bevilacqua, M., Sinigaglia, M. R. \& Corbo. Alicyclobacillus acidoterrestris: new methods for inhibiting spore germination. International Journal of Food Microbiology 125 (2), $103-10$ (2008).

6. Maldonado, M.C., Aban, M.P. \& Navarro, A.R. Chemical and essential oil effect on Alicyclobacillus acidoterrestris viability. Brazilian Journal of Microbiology 44(4): 1133 - 1137 (2013).

7. Markland, S.M., Farkas, D.F., Kniel, K.E. \& Hoover, D.G. Pathogenic psychrotolerant sporeformers: An emerging challenge for low-temperature storage of minimally processed foods. Foodborne Pathogens and Disease 10, $413-419$ (2013).

8. Lucking, G., Dommel, M.K., Scherer, S., Fouet, A. \& Ehling-Schulz, M. Cereulide synthesis in emetic Bacillus cereus is controlled by the transition state regulator AbrB, but not by the virulence regulator PIcR. Journal of Microbiology 155, 922 - 931 (2009).

9. Carlin, F. Origin of bacterial spores contaminating foods. Food Microbiology 28, $177-182$ (2011).

10. Deak, T. Thermal treatment. In Technologies and Food Safety Chapter 17, 423 - 442. (2014).

11. Chipley, J. R. Sodium benzoate and benzoic acid. In Davidson, J.N.S.P.M.,B., A.L. (Eds.), Antimicrobials in Food, Tayler \& Francis Group, Boca Raton, FL 1148 (2005).

12. Glass, K. A., McDonnell, L. M., Rassel, R. C. \& Zierke, K. L. Controlling Listeria monocytogenes on sliced ham and turkey products using benzoate, propionate, and sorbate. Journal of Food Protection 70, 2306-2312 (2007).

13. Mani-Lopez, E., García, H. S. \& Lopez-Malo, A. Organic acids as antimicrobials to control Salmonella in meat and poultry products. Food Research. International 45, 713-721 (2012).

14. Ngono, E. F. Evaluation des activites antibacterienne et antiradicalairein vitro des huiles essentielles de Drypetes gossweileri et Pentadiplandra brazzeana. Master Dissertation, University of Yaounde I, Cameroon (2008)

15. Voundi, O. S., Nyegue, M., Lazar, I., Raducanu, D., Ndoye, F., Marius, S. \& Etoa, F.-X. Effect of essential oils on germination and growth of some pathogenic and spoilage spore-forming bacteria. Foodborne Pathogens and Disease 12, 551-559 (2015).

16. Voundi, O. S., Nyegue, M. A., Lazar, I., Stamate, M., Raducanu, D., Rati, I. V. \& Etoa, F.-X. Effect of Drypetes gossweileri essential oil and irradiation treatments on inhibition and sensitivity of bacterial spores. Food Science and Technology International 26 (1), 1-13 (2020).

17. Alnoman, M., Udompijitkul, P., Paredes-Sabja, D. \& Sarker, M. R. The inhibitory effects of sorbate and benzoate against Clostridium perfringens type A isolates. Food Microbiology 48, 89 - 98 (2015).

18. Bayoï, J. R. et al. Activity of acetic acid on Bacillus stearothermophilus and Bacillus subtilis spores after sublethal pretreatments. International Journal of Innovative and Scientific Research 10, 570-575 (2014).

19. van Melis, C. C. J., Groot, N. M. N., Tempelaars, M. H., Moezelaar, R. \& Abee, T. Characterizaation of germination and outgrowth of sorbic acid-stressed Bacillus cereus ATCC 14579 spores: phenotype and transcriptome analysis. Food Microbiology 28, 275-283 (2012).

20. Velugotia, P. R., Rajagopala, L., Junejab, V. \& Thippareddia, H. Use of calcium, potassium, and sodium lactates to control germination and outgrowth of Clostridium perfringens spores during chilling of injected pork. Food Microbiology 24, 687 - 694 (2007).

21. Bogaert, J.C. \& Naidu, A.S. Lactic acid. In Natural Food Antimicrobial Systems (Naidu, A.S. Ed.), CRC press 613 - 636 (London 2000 ).

22. Brul, S. et al. Physiological actions ofpreservative agents: prospective of use ofmodern microbiological techniques inassessing microbial behavior in food preservation. International Journal of FoodMicrobiology 79, 55-64 (2002).

23. Chu, S., Hawes, J. W. \& Lorigan, G. A. Solid-state NMR spectroscopic studies on the interaction of sorbic acid with phospholipid membranes at different pH levels. Magnetic Resonance in Chemistry 47, 654 - 657 (2009).

24. Burt, S., Vlielander, R., Haagsman, H. \& Veldhuizen, E. Increase in activity of essential oil components carvacrol and thymol against Escherichia coli 0157:H7 by addition of food stabilizers. Journal of Food Protection 68, 919-926 (2005).

25. Verma, R. P. Synthesis and reactions of 3-oxobutyl isothiocyanate (OB ITC). European Journal of Organic Chemistry 3, 415-420 (2003).

26. Juven, B. J., Kanner, J., Schved, F. \& Weisslowicz, H. Factors that interact with the antibacterial action of thyme essential oil and its active constituents. Journal of Applied Bacteriology 76, 626 - 631 (1994).

\section{Tables}

Table 1

Coded and uncoded values of real independent variables

\begin{tabular}{|lllll|}
\hline Level & Coded values & \multicolumn{4}{l|}{ Uncoded values } \\
\hline & & $\mathrm{X}_{1}(\mu \mathrm{g} / \mathrm{mL})$ & $\mathrm{X}_{2}(\%)$ & $\mathrm{X}_{3}$ \\
\hline low & -1 & 0.62 & 0.01 & 4.50 \\
\hline middle & 0 & 5.31 & 0.05 & 5.75 \\
High & +1 & 10.00 & 0.10 & 7.00 \\
\hline
\end{tabular}

Page 7/17 
Table 2

Randomized Box-Behnken design used for combined effect of D. gossweileri EO and organic acids on germination and growth of bacterial spores.

\begin{tabular}{|c|c|c|c|c|}
\hline \multirow[t]{2}{*}{ Run order } & \multirow[t]{2}{*}{ Test number } & \multicolumn{3}{|l|}{ Uncoded factors } \\
\hline & & Essential oil ( $\mu \mathrm{g} / \mathrm{ml})$ & Organic acid (\%) & $\mathrm{pH}$ \\
\hline 6 & 1 & 10.00 & 0.05 & 4.50 \\
\hline 7 & 2 & 0.62 & 0.05 & 7.00 \\
\hline 12 & 3 & 5.31 & 0.10 & 7.00 \\
\hline 11 & 4 & 5.31 & 0.01 & 7.00 \\
\hline 2 & 5 & 10.00 & 0.01 & 5.75 \\
\hline 22 & 6 & 0.62 & 0.05 & 7.00 \\
\hline 5 & 7 & 0.62 & 0.05 & 4.50 \\
\hline 27 & 8 & 5.31 & 0.10 & 7.00 \\
\hline 16 & 9 & 0.62 & 0.01 & 5.75 \\
\hline 24 & 10 & 5.31 & 0.01 & 4.50 \\
\hline 26 & 11 & 5.31 & 0.01 & 7.00 \\
\hline 8 & 12 & 10.00 & 0.05 & 7.00 \\
\hline 13 & 13 & 5.31 & 0.05 & 5.75 \\
\hline 14 & 14 & 5.31 & 0.05 & 5.75 \\
\hline 17 & 15 & 10.00 & 0.01 & 5.75 \\
\hline 4 & 16 & 10.00 & 0.10 & 5.75 \\
\hline 10 & 17 & 5.31 & 0.10 & 4.50 \\
\hline 20 & 18 & 0.62 & 0.05 & 4.50 \\
\hline 28 & 19 & 5.31 & 0.05 & 5.75 \\
\hline 15 & 20 & 5.31 & 0.05 & 5.75 \\
\hline 18 & 21 & 0.62 & 0.10 & 5.75 \\
\hline 29 & 22 & 5.31 & 0.05 & 5.75 \\
\hline 21 & 23 & 10.00 & 0.05 & 4.50 \\
\hline 25 & 24 & 5.31 & 0.10 & 4.50 \\
\hline 1 & 25 & 0.62 & 0.01 & 5.75 \\
\hline 23 & 26 & 10.00 & 0,05 & 7.00 \\
\hline 30 & 27 & 5.31 & 0.05 & 5.75 \\
\hline 9 & 28 & 5.31 & 0.01 & 4.50 \\
\hline 19 & 29 & 10.00 & 0.10 & 5.75 \\
\hline 3 & 30 & 0.62 & 0.10 & 5.75 \\
\hline
\end{tabular}

Table 3

Percentages inhibition of germination and spore growth under the combined effect of $D$. gossweileri $\mathrm{EO}, \mathrm{Na}^{+}$benzoate and $\mathrm{pH}$. 


\begin{tabular}{|c|c|c|c|c|c|c|c|}
\hline \multirow[t]{2}{*}{ Test number } & \multicolumn{3}{|c|}{ Coded values of factors } & \multicolumn{4}{|c|}{ Percentages inhibition of spores germination and growth after 48 hours } \\
\hline & $\mathrm{X}_{1}$ & $x_{2}$ & $x_{3}$ & B. cereus & B. megaterium & B. subtilis & B. stearothermophilus \\
\hline 1 & 1 & 0 & 1 & 100.00 & 99.53 & 99.54 & 98.42 \\
\hline 2 & -1 & 0 & 1 & 49.36 & 13.41 & 53.05 & 59.15 \\
\hline 3 & 0 & 1 & 1 & 59.55 & 0 & 51.68 & 64.28 \\
\hline 4 & 0 & -1 & 1 & 57.56 & 0 & 0.63 & 61.85 \\
\hline 5 & 1 & -1 & 0 & 57.80 & 98.439 & 0 & 64.47 \\
\hline 6 & -1 & 0 & 1 & 44.98 & 7.488 & 60.00 & 59.15 \\
\hline 7 & -1 & 0 & -1 & 100.00 & 97.81 & 99.54 & 98.03 \\
\hline 8 & 0 & 1 & 1 & 59.55 & 0 & 48.31 & 64.28 \\
\hline 9 & -1 & -1 & 0 & 61.62 & 0 & 51.59 & 50.36 \\
\hline 10 & 0 & -1 & -1 & 100.00 & 98.12 & 99.90 & 97.83 \\
\hline 11 & 0 & -1 & 1 & 57.56 & 0 & 1.00 & 61.85 \\
\hline 12 & 1 & 0 & 1 & 64.25 & 22.46 & 0 & 77.93 \\
\hline 13 & 0 & 0 & 0 & 100.00 & 9.36 & 37.53 & 92.71 \\
\hline 14 & 0 & 0 & 0 & 100.00 & 29.32 & 13.42 & 89.29 \\
\hline 15 & 1 & -1 & 0 & 99.52 & 99.68 & 30.50 & 100,00 \\
\hline 16 & 1 & 1 & 0 & 100.00 & 100.00 & 99.17 & 100.00 \\
\hline 17 & 0 & 1 & -1 & 100.00 & 97.97 & 99.90 & 98.81 \\
\hline 18 & -1 & 0 & -1 & 99.60 & 98.90 & 99.54 & 92.71 \\
\hline 19 & 0 & 0 & 0 & 100.00 & 26.20 & 37.53 & 89.10 \\
\hline 20 & 0 & 0 & 0 & 100.00 & 34.94 & 35.89 & 86.80 \\
\hline 21 & -1 & 1 & 0 & 100.00 & 35.72 & 65.75 & 56.40 \\
\hline 22 & 0 & 0 & 0 & 100.00 & 11.23 & 17.80 & 91.33 \\
\hline 23 & 1 & 0 & -1 & 100.00 & 97.97 & 98.72 & 97.96 \\
\hline 24 & 0 & 1 & -1 & 100.00 & 100.00 & 100.00 & 98.68 \\
\hline 25 & -1 & -1 & 0 & 66.87 & 0.15 & 63.01 & 57.32 \\
\hline 26 & 1 & 0 & 1 & 73.487 & 0 & 11.14 & 77.93 \\
\hline 27 & 0 & 0 & 0 & 100.00 & 18.87 & 12.87 & 89.29 \\
\hline 28 & 0 & -1 & -1 & 100.00 & 22.46 & 99.54 & 98.42 \\
\hline 29 & 1 & 1 & 0 & 100.00 & 100.00 & 99.17 & 100.00 \\
\hline 30 & -1 & 1 & 0 & 100.00 & 53.19 & 61.38 & 84.89 \\
\hline
\end{tabular}

$\mathrm{X}_{1}=$ D. gossweileri $\mathrm{EO}(\mu \mathrm{g} / \mathrm{mL}) ; \mathrm{X}_{2}=\mathrm{Na}^{+}$Benzoate $(\%)$ and $\mathrm{X}_{3}=\mathrm{pH}$

Table 4

Percentages inhibition of germination and spores growth under the combined effect of D. gossweileri EO, $\mathrm{Na}^{+}$lactate and $\mathrm{pH}$. 


\begin{tabular}{|c|c|c|c|c|c|c|c|}
\hline \multirow[t]{2}{*}{ Test number } & \multicolumn{3}{|c|}{ Coded values of factors } & \multicolumn{4}{|c|}{ Percentages inhibition of spores germination and growth after 48 hours (\%) } \\
\hline & $x_{1}$ & $x_{2}$ & $x_{3}$ & B. cereus & B. megaterium & B. subtilis & B. stearothermophilus \\
\hline 1 & 1 & 0 & -1 & 100.00 & 98.62 & 100.00 & 99.89 \\
\hline 2 & -1 & 0 & 1 & 19.42 & 0.00 & 0.00 & 21.13 \\
\hline 3 & 0 & 1 & 1 & 31.87 & 42.66 & 54.24 & 41.51 \\
\hline 4 & 0 & -1 & 1 & 42.61 & 22.07 & 41.52 & 31.00 \\
\hline 5 & 1 & -1 & 0 & 63.75 & 38.03 & 0.00 & 50.32 \\
\hline 6 & -1 & 0 & 1 & 19.42 & 19.41 & 0.00 & 21.13 \\
\hline 7 & -1 & 0 & -1 & 100.00 & 99.97 & 100.00 & 98.83 \\
\hline 8 & 0 & 1 & 1 & 31.44 & 42.66 & 50.47 & 41.51 \\
\hline 9 & -1 & -1 & 0 & 58.08 & 72.91 & 4.24 & 74.63 \\
\hline 10 & 0 & -1 & -1 & 100.00 & 99.41 & 100.00 & 100.00 \\
\hline 11 & 0 & -1 & 1 & 52.49 & 22.07 & 51.57 & 31.00 \\
\hline 12 & 1 & 0 & 1 & 35.14 & 18.42 & 0.00 & 36.40 \\
\hline 13 & 0 & 0 & 0 & 43.04 & 38.62 & 56.20 & 76.43 \\
\hline 14 & 0 & 0 & 0 & 43.04 & 21.18 & 56.59 & 71.34 \\
\hline 15 & 1 & -1 & 0 & 100.00 & 98.82 & 2.83 & 100.00 \\
\hline 16 & 1 & 1 & 0 & 84.28 & 98.72 & 62.64 & 100.00 \\
\hline 17 & 0 & 1 & -1 & 100.00 & 98.92 & 100.00 & 100.00 \\
\hline 18 & -1 & 0 & -1 & 100.00 & 99.80 & 97.49 & 100.00 \\
\hline 19 & 0 & 0 & 0 & 49.74 & 36.75 & 69.47 & 71.34 \\
\hline 20 & 0 & 0 & 0 & 49.74 & 41.18 & 56.04 & 72.51 \\
\hline 21 & -1 & 1 & 0 & 48.54 & 11.53 & 0.00 & 82.59 \\
\hline 22 & 0 & 0 & 0 & 43.04 & 39.51 & 51.10 & 76.43 \\
\hline 23 & 1 & 0 & -1 & 100.00 & 98.82 & 100.00 & 100.00 \\
\hline 24 & 0 & 1 & -1 & 100.00 & 98.52 & 96.86 & 99.79 \\
\hline 25 & -1 & -1 & 0 & 48.20 & 76,65 & 0.00 & 72.93 \\
\hline 26 & 1 & 0 & 1 & 35.14 & 35.67 & 0.00 & 36.94 \\
\hline 27 & 0 & 0 & 0 & 43.04 & 49.36 & 54.40 & 74.52 \\
\hline 28 & 0 & -1 & -1 & 96.13 & 99.90 & 100.00 & 100.00 \\
\hline 29 & 1 & 1 & 0 & 100.00 & 100.00 & 62.64 & 100.00 \\
\hline 30 & -1 & 1 & 0 & 55.58 & 11.53 & 0.00 & 55.31 \\
\hline
\end{tabular}

$\mathrm{X}_{1}=$ D. gossweileri EO $(\mu \mathrm{g} / \mathrm{mL}) ; \mathrm{X}_{2}=\mathrm{Na}^{+}$Lactate $(\%)$ and $\mathrm{X}_{3}=\mathrm{pH}$

Table 5

Percentages inhibition of germination and spores growth under the combined effect of $D$. gossweileri EO, sorbic acid and $\mathrm{pH}$. 


\begin{tabular}{|c|c|c|c|c|c|c|c|}
\hline \multirow[t]{2}{*}{ Test number } & \multicolumn{3}{|c|}{ Coded values of factors } & \multicolumn{4}{|c|}{ Percentages inhibition of spores germination and growth after 48 hours (\%) } \\
\hline & $x_{1}$ & $x_{2}$ & $x_{3}$ & B. cereus & B. megaterium & B. subtilis & B. stearothermophilus \\
\hline 1 & 1 & 0 & -1 & 100.00 & 99.34 & 97.95 & 97.12 \\
\hline 2 & -1 & 0 & 1 & 7.73 & 11.41 & 39.20 & 39.79 \\
\hline 3 & 0 & 1 & 1 & 36.91 & 48.81 & 49.49 & 19.11 \\
\hline 4 & 0 & -1 & 1 & 57.77 & 64.32 & 16.25 & 23.30 \\
\hline 5 & 1 & -1 & 0 & 61.55 & 49.87 & 30.34 & 38.61 \\
\hline 6 & -1 & 0 & 1 & 20.86 & 11.41 & 39.20 & 31.81 \\
\hline 7 & -1 & 0 & -1 & 100.00 & 99.34 & 98.69 & 96.47 \\
\hline 8 & 0 & 1 & 1 & 24.81 & 48.81 & 54.09 & 7.59 \\
\hline 9 & -1 & -1 & 0 & 76.39 & 88.66 & 6.36 & 33.12 \\
\hline 10 & 0 & -1 & -1 & 100.00 & 99.40 & 99.55 & 97.91 \\
\hline 11 & 0 & -1 & 1 & 23.00 & 64.32 & 16.25 & 28.93 \\
\hline 12 & 1 & 0 & 1 & 42.92 & 60.15 & 47.78 & 46.99 \\
\hline 13 & 0 & 0 & 0 & 100.00 & 99.80 & 85.40 & 81.81 \\
\hline 14 & 0 & 0 & 0 & 100.00 & 99.80 & 84.55 & 78.14 \\
\hline 15 & 1 & -1 & 0 & 83.09 & 100.00 & 82.67 & 99.48 \\
\hline 16 & 1 & 1 & 0 & 100.00 & 99.60 & 99.15 & 100.00 \\
\hline 17 & 0 & 1 & -1 & 100.00 & 99.73 & 98.47 & 97.51 \\
\hline 18 & -1 & 0 & -1 & 100.00 & 99.34 & 100.00 & 97.64 \\
\hline 19 & 0 & 0 & 0 & 96.91 & 99.80 & 85.40 & 84.95 \\
\hline 20 & 0 & 0 & 0 & 100.00 & 99.80 & 84.55 & 66.49 \\
\hline 21 & -1 & 1 & 0 & 62.75 & 100.00 & 98.69 & 80.24 \\
\hline 22 & 0 & 0 & 0 & 100.00 & 99.80 & 88.47 & 78.14 \\
\hline 23 & 1 & 0 & -1 & 100.00 & 99.34 & 98,92 & 96.73 \\
\hline 24 & 0 & 1 & -1 & 100.00 & 99.67 & 41.88 & 97.51 \\
\hline 25 & -1 & -1 & 0 & 84.64 & 88.40 & 11.48 & 33.12 \\
\hline 26 & 1 & 0 & 1 & 29.96 & 66.25 & 52.44 & 46.99 \\
\hline 27 & 0 & 0 & 0 & 99.57 & 99.80 & 84.49 & 78.14 \\
\hline 28 & 0 & -1 & -1 & 100.00 & 99.34 & 98.52 & 99.21 \\
\hline 29 & 1 & 1 & 0 & 100.00 & 100.00 & 99.89 & 95.29 \\
\hline 30 & -1 & 1 & 0 & 60.60 & 100.00 & 98.75 & 82.85 \\
\hline
\end{tabular}

$\mathrm{X}_{1}=$ D. gossweileri $\mathrm{EO}(\mu \mathrm{g} / \mathrm{mL}) ; \mathrm{X}_{2}=$ Sorbic acid $(\%)$ and $\mathrm{X}_{3}=\mathrm{pH}$

Table 6

Analysis of variance for screening experiments of the combined effect of $D$. gossweileri essential oil, $\mathrm{Na}^{+}$benzoate and pH on germination and growth of Bacillus species 


\begin{tabular}{|c|c|c|c|c|c|c|c|c|c|c|c|c|c|c|c|}
\hline \multicolumn{2}{|c|}{ Source } & \multicolumn{4}{|l|}{ B. cereus } & \multicolumn{4}{|c|}{ B. megaterium } & \multicolumn{4}{|l|}{ B. subtilis } & \multicolumn{2}{|c|}{ G. stearothen } \\
\hline & Df & SS & MS & $\mathbf{F}$ & $\mathbf{P}$ & SS & MS & $F$ & $\mathbf{P}$ & SS & MS & $\mathbf{F}$ & $\mathbf{P}$ & SS & N \\
\hline Model & 9 & 10388.8 & 1154.3 & 13.5 & $0.00 *$ & 43765.6 & 4862.84 & 9.96 & $0.00 *$ & 38080.8 & 4231.20 & 35.99 & $0.00 *$ & 13926.4 & 1 \\
\hline$X_{1}$ & 1 & 329.52 & 329.52 & 5.98 & $0.02^{\star}$ & 6060.17 & 6060.17 & 27.02 & $0.00 *$ & 835.71 & 835.71 & 10.20 & $0.00 *$ & 1574.1 & $1 !$ \\
\hline$x_{2}$ & 1 & 872.50 & 872.50 & 15.84 & $0.00 *$ & 1764.39 & 1764.39 & 7.87 & $0.01^{*}$ & 4871.91 & 4871.91 & 59.44 & $0.00 *$ & 353.87 & $3 !$ \\
\hline$x_{3}$ & 1 & 6942.23 & 6942.23 & 126.03 & 0.00 * & 28007.9 & 28007.9 & 124.86 & $0.00 *$ & 20368.1 & 20368.1 & 248.49 & $0.00 *$ & 4045.98 & 41 \\
\hline$x_{1}{ }^{2}$ & 1 & 392.98 & 392.98 & 7.13 & 0.01 * & 5407.57 & 5407.57 & 24.11 & $0.00 *$ & 2333.2 & 2333,2 & 28,47 & $0.00 *$ & 230.02 & $2:$ \\
\hline$x_{1} x_{2}$ & 1 & 103.83 & 103.83 & 1.89 & 0.18 & 943.85 & 943.853 & 4.21 & 0.05 & 3015.7 & 3015.7 & 36.79 & $0,00 *$ & 0.45 & 0 . \\
\hline$x_{1} x_{3}$ & 1 & 231.05 & 231.05 & 4.19 & 0.05 & 0.07 & 0.07 & 0.00 & 0.98 & 1277.55 & 1277.55 & 15.59 & 0.00 * & 127.28 & 1: \\
\hline$x_{2}{ }^{2}$ & 1 & 359.42 & 359.42 & 6.53 & $0.02^{\star}$ & 1095,79 & 1095.79 & 4.88 & $0.04^{\star}$ & 1707.63 & 1707.63 & 20.83 & $0.00 *$ & 414.65 & 4 \\
\hline$x_{2} x_{3}$ & 1 & 1.98 & 1.98 & 0.04 & 0.85 & 748.44 & 748.441 & 3.34 & 0.08 & 1198.04 & 1198.04 & 14.62 & $0.00 *$ & 1.63 & 1. \\
\hline$x_{3}{ }^{2}$ & 1 & 1394.94 & 1394.94 & 25.32 & $0.00 *$ & 264.09 & 264.098 & 1.18 & 0.29 & 3437.14 & 3437.14 & 41.93 & $0.00 *$ & 16.84 & 11 \\
\hline Res. & 20 & 1709.5 & 85.47 & & & 9769.0 & 488.45 & & & 2351.5 & 117.58 & & & 3842.5 & $1^{\prime}$ \\
\hline $\begin{array}{l}\text { P. } \\
\text { error }\end{array}$ & 17 & 936.39 & 55.08 & & & 3813.44 & 224.32 & & & 1393.44 & 81.96 & & & 1096.38 & 6 \\
\hline Total & 29 & 12098.3 & & & & 53534.6 & & & & 40432.3 & & & & 8428.85 & \\
\hline $\begin{array}{l}\text { Predic } \\
\mathrm{R}^{2}\end{array}$ & & $85.8702 \%$ & & & & $81.752 \%$ & & & & $94.1841^{\circ}$ & & & & 79.5664 & \\
\hline Adjust & $R^{2}$ & $79.5118 \%$ & & & & 73.5404 \% & & & & 91.5669 ? & & & & 70.3712 & \\
\hline \multicolumn{2}{|c|}{$\begin{array}{l}\text { Regression } \\
\text { equations } \\
\text { of the } \\
\text { reduced } \\
\text { fitted model }\end{array}$} & \multicolumn{4}{|c|}{$\begin{array}{l}Y(\%)=100+4.53 X_{1}+7.38 X_{2}-20.83 \\
X_{3}-7.29 X_{1}^{2}-6.97 X_{2}^{2}-13.74 X_{3}^{2}\end{array}$} & \multicolumn{4}{|c|}{$\begin{array}{l}Y(\%)=25.33+19,46 X_{1}+10.50 X_{2}- \\
41.83 X_{3}+26.60 X_{1}^{2}+11.72 X_{2}^{2}\end{array}$} & \multicolumn{4}{|c|}{$\begin{array}{l}Y(\%)=25,84-7.22 X_{1}+17.44 X_{2-}^{-} \\
35.67 X_{3}+17.77 X_{1}^{2}+19.41 X_{1} X_{2}^{-} \\
12.63 X_{1} X_{3}+15.20 X_{2}^{2}+12.23 X_{2} X_{3}+ \\
21.57 X_{3}^{2}\end{array}$} & \multicolumn{2}{|c|}{$\begin{array}{l}Y(\%)=85.70 \\
15.90 X_{3}-6 .\end{array}$} \\
\hline
\end{tabular}

Df = Degre of freedom; SS= Sum of squares; MS = Mean square; F = Lack of fit F-value; P = P-value; $\mathrm{X} 1=D$. gossweileri EO; $\mathrm{X}_{2}=\mathrm{Na}+$ benzoate; $\mathrm{X}_{3}=\mathrm{pH} ; \mathrm{Res}$. $=$ Residual; P. error = Pure error; * indicate significant of the model, the variables, the interactions and the quadratic parameters ( $\mathrm{p} \otimes 0.05)$.

Table 7

Analysis of variance for screening experiments of the combined effect of $D$. gossweileri essential oil, $\mathrm{Na}^{+}$lactate and $\mathrm{pH}$ on the germination and growth of Bacillus species 


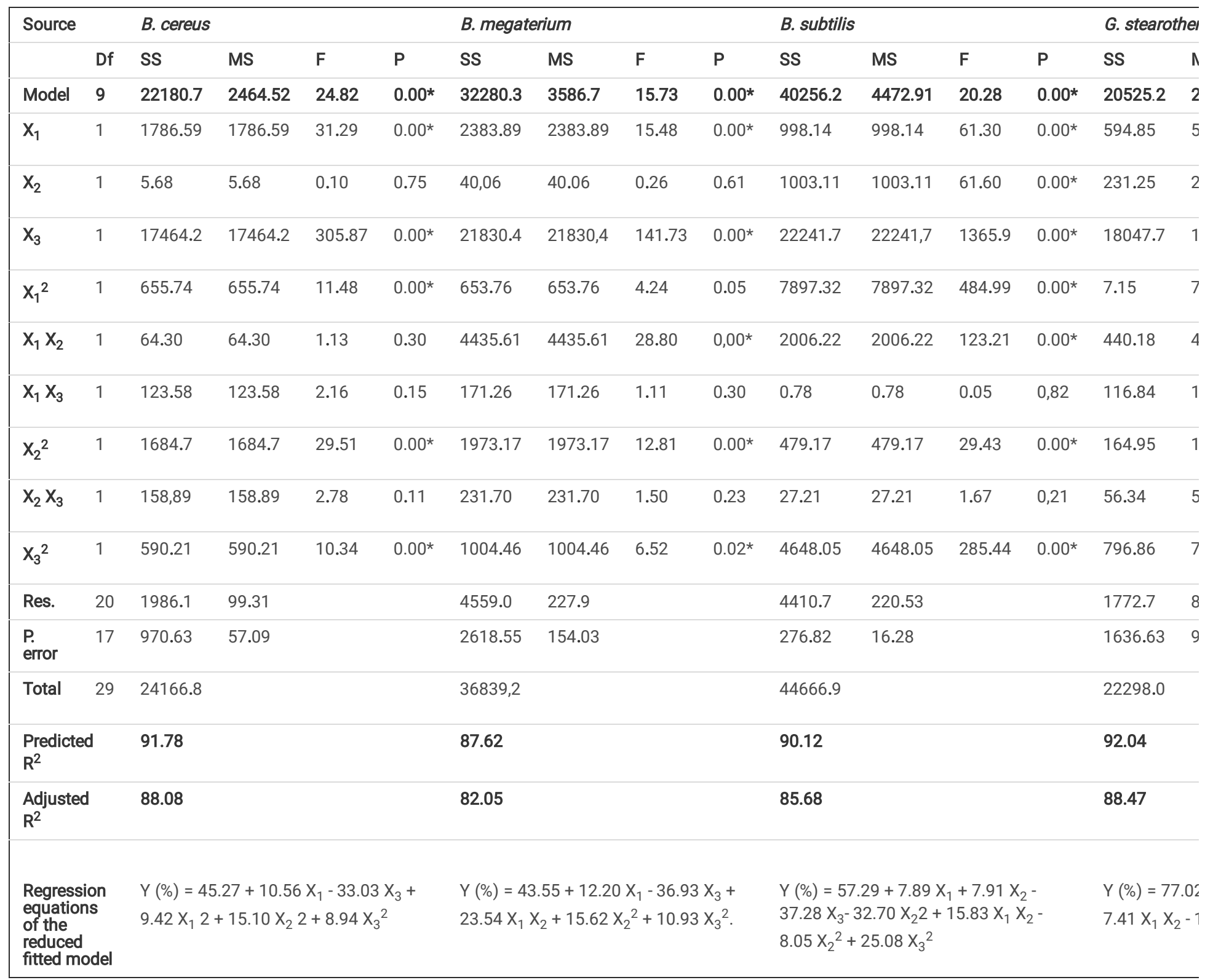

$\mathrm{Df}=$ Degre of freedom; $\mathrm{SS}=$ Sum of squares; $\mathrm{MS}=$ Mean square; $\mathrm{F}=$ Lack of fit F-value; $\mathrm{P}=\mathrm{P}$-value; $\mathrm{X}_{1}=$ D. gossweileri $\mathrm{EO} ; \mathrm{X}_{2}=\mathrm{Na}+$ benzoate; $\mathrm{X}_{3}=\mathrm{pH} ; \mathrm{Res}$. Residual; P. error $=$ Pure error; $\left.{ }^{*}\right)=$ indicate significant of the model, the variables, the interactions and the quadratic parameters $(p \otimes 0.05)$.

\section{Table 8}

Analysis of variance for screening experiments of the combined effect of $D$. gossweileri essential oil, Sorbic acid and $\mathrm{pH}$ on the germination and growth of Bacillus species. 


\begin{tabular}{|c|c|c|c|c|c|c|c|c|c|c|c|c|c|c|c|}
\hline \multicolumn{2}{|c|}{ Source } & \multicolumn{4}{|l|}{ B. cereus } & \multicolumn{4}{|c|}{ B. megaterium } & \multicolumn{4}{|c|}{ B. subtilis } & \multicolumn{2}{|c|}{ G. stearothern } \\
\hline & Df & SS & MS & $\mathbf{F}$ & $\mathbf{P}$ & SS & MS & $\mathbf{F}$ & $\mathbf{P}$ & SS & MS & $\mathbf{F}$ & $\mathbf{P}$ & SS & $M:$ \\
\hline Model & 9 & 26676.6 & 2964.07 & 44.60 & $0.00 *$ & 17156.9 & 1906.32 & 11.29 & $0.00 *$ & 22446.1 & 2494.01 & 6.76 & $0.00 *$ & 21558.7 & 23 \\
\hline $\mathrm{X}_{1}$ & 1 & 683.16 & 683.16 & 10.33 & $0.00 *$ & 360.95 & 360.95 & 4.81 & $0.04^{*}$ & 852.07 & 852.07 & 4.80 & $0.04^{*}$ & 995.05 & 99 \\
\hline$x_{2}$ & 1 & 0.11 & 0.11 & 0.00 & 0.96 & 111.87 & 111.87 & 1.49 & 0,23 & 4864.27 & 4864.27 & 27.39 & $0.00 *$ & 999.18 & 99 \\
\hline$x_{3}$ & 1 & 19324.6 & 19324.6 & 292.34 & $0.00^{*}$ & 11026.4 & 11026.4 & 146.98 & $0,00^{*}$ & 10986.3 & 10986.3 & 61.87 & $0.00 *$ & 17929.4 & 17 \\
\hline $\mathrm{x}_{1}{ }^{2}$ & 1 & 1239.91 & 1239.91 & 18.76 & $0.00^{*}$ & 646.74 & 646,74 & 8,62 & $0.00 *$ & 92.876 & 92.876 & 0.52 & 0.47 & 13.45 & 13 \\
\hline$x_{1} x_{2}$ & 1 & 1082.22 & 1082.22 & 16.37 & $0.00 *$ & 89.71 & 89.71 & 1.20 & 0.28 & 1094.64 & 1094.64 & 6.16 & $0.02^{*}$ & 196.61 & 19 \\
\hline$x_{1} x_{3}$ & 1 & 245.22 & 245.22 & 3.71 & 0.07 & 1341.13 & 1341.13 & 17.88 & $0.00 *$ & 69.83 & 69.83 & 0.39 & 0.53 & 64.09 & 64 \\
\hline$x_{2}{ }^{2}$ & 1 & 452.63 & 452.63 & 6.85 & $0.01^{*}$ & 1.02 & 1.02 & 0.01 & 0.90 & 1893.04 & 1893.04 & 10.66 & $0.00 *$ & 592.55 & 59 \\
\hline$x_{2} x_{3}$ & 1 & 45.39 & 45.39 & 0.69 & 0.41 & 125.59 & 125.59 & 1.67 & 0.21 & 2073.9 & 2073.9 & 11.68 & $0.00 *$ & 68.61 & 68 \\
\hline$x_{3}{ }^{2}$ & 1 & 4173.54 & 4173.54 & 63.14 & $0.00 *$ & 3614.45 & 3614.45 & 48.18 & $0.00 *$ & 761.00 & 761.00 & 4.29 & 0.05 & 753.76 & 75 \\
\hline Res. & 20 & 1329.3 & 66.46 & & & 3377.9 & 168.89 & & & 7377.9 & 368.90 & & & 5175.8 & 25 \\
\hline $\begin{array}{l}\text { P. } \\
\text { error }\end{array}$ & 17 & 1123.76 & 66.10 & & & 1275.37 & 75.02 & & & 3018.75 & 177.574 & & & 2177.64 & 12 \\
\hline Total & 29 & 28005.9 & & & & 20534.8 & & & & 29824.0 & & & & 26734.5 & \\
\hline $\begin{array}{l}\text { Predict } \\
\mathrm{R}^{2}\end{array}$ & & 95.25 & & & & 83.55 & & & & 75.26 & & & & 80.63 & \\
\hline Adjust & $R^{2}$ & 93.11 & & & & 76.14 & & & & 64.12 & & & & 71.92 & \\
\hline \multicolumn{2}{|c|}{$\begin{array}{l}\text { Regression } \\
\text { equations } \\
\text { of the } \\
\text { reduced } \\
\text { fitted model }\end{array}$} & \multicolumn{4}{|c|}{$\begin{array}{l}Y(\%)=99.41+6.53 X_{1}-34.75 X_{3}- \\
12.95 X_{1}{ }^{2}+11.63 X_{1} X_{2}-7.82 X_{2}{ }^{2}- \\
23.77 X_{3}{ }^{2}\end{array}$} & \multicolumn{4}{|c|}{$\begin{array}{l}Y(\%)=100.03-26.25 X_{3}-9.38 X_{1}^{2}+ \\
12.94 X_{1} X_{3}-22.15 X_{3}^{2}\end{array}$} & \multicolumn{4}{|c|}{$\begin{array}{l}Y(\%)=77.64+7.29 X_{1}+17.43 X_{2}- \\
26.20 X_{3}-11.69 X_{1} X_{2}-15.03 X_{2}^{2}+ \\
16.10 X_{2} X_{3}\end{array}$} & \multicolumn{2}{|c|}{$\begin{array}{l}Y(\%)=78.77 \\
33.47 X_{3}-9.06\end{array}$} \\
\hline
\end{tabular}

Legend: $\mathrm{Df}=$ Degre of freedom; $\mathrm{SS}=$ Sum of squares; $\mathrm{MS}=$ Mean square; $\mathrm{F}=$ Lack of fit $F$-value; $\mathrm{P}=\mathrm{P}$-value; $\mathrm{X}_{1}=\mathrm{D}$. gossweileri EO; $\mathrm{X}_{2}=\mathrm{Na}{ }^{+}$benzoate; $\mathrm{X}_{3}=$ $\mathrm{pH} ;$ Res. $=$ Residual; $\mathrm{P}$. error $=$ Pure error; $\left(^{\star}\right)=$ indicate significant of the model, the variables, the interactions and the quadratic parameters $(\mathrm{p} \otimes 0.05)$

\section{Figures}




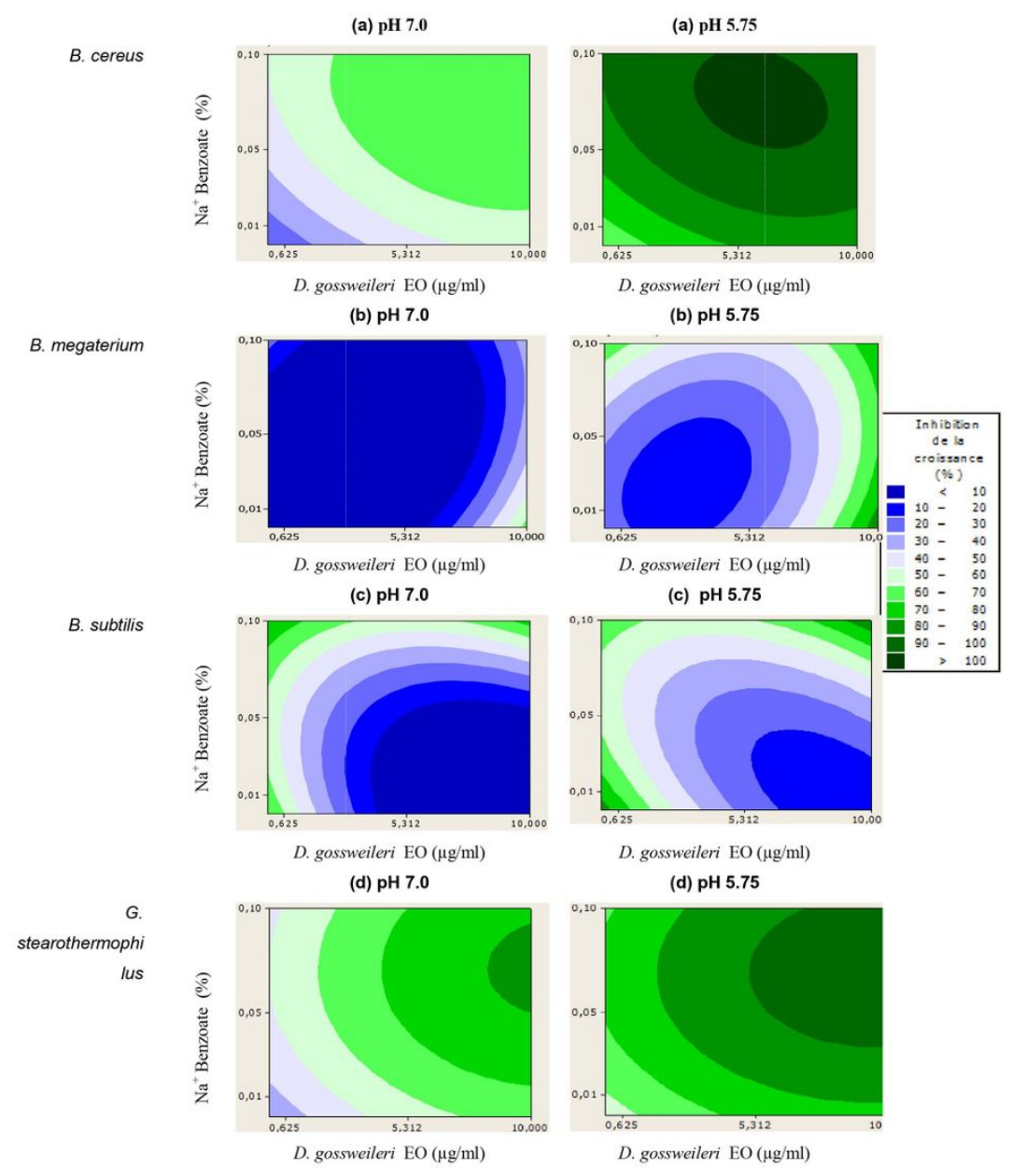

\section{Figure 1}

Contours plots of the percentages inhibition of spores germination and growth at different concentrations of $D$. gossweileri EO, Na ${ }^{+} \mathrm{Benzoate}$ and $\mathrm{pH}$; with (a) $=B$. cereus $;(\mathbf{b})=B$. megaterium; $(\mathbf{c})=B$. subtilis; $(\mathbf{d})=G$. stearothermophilus 


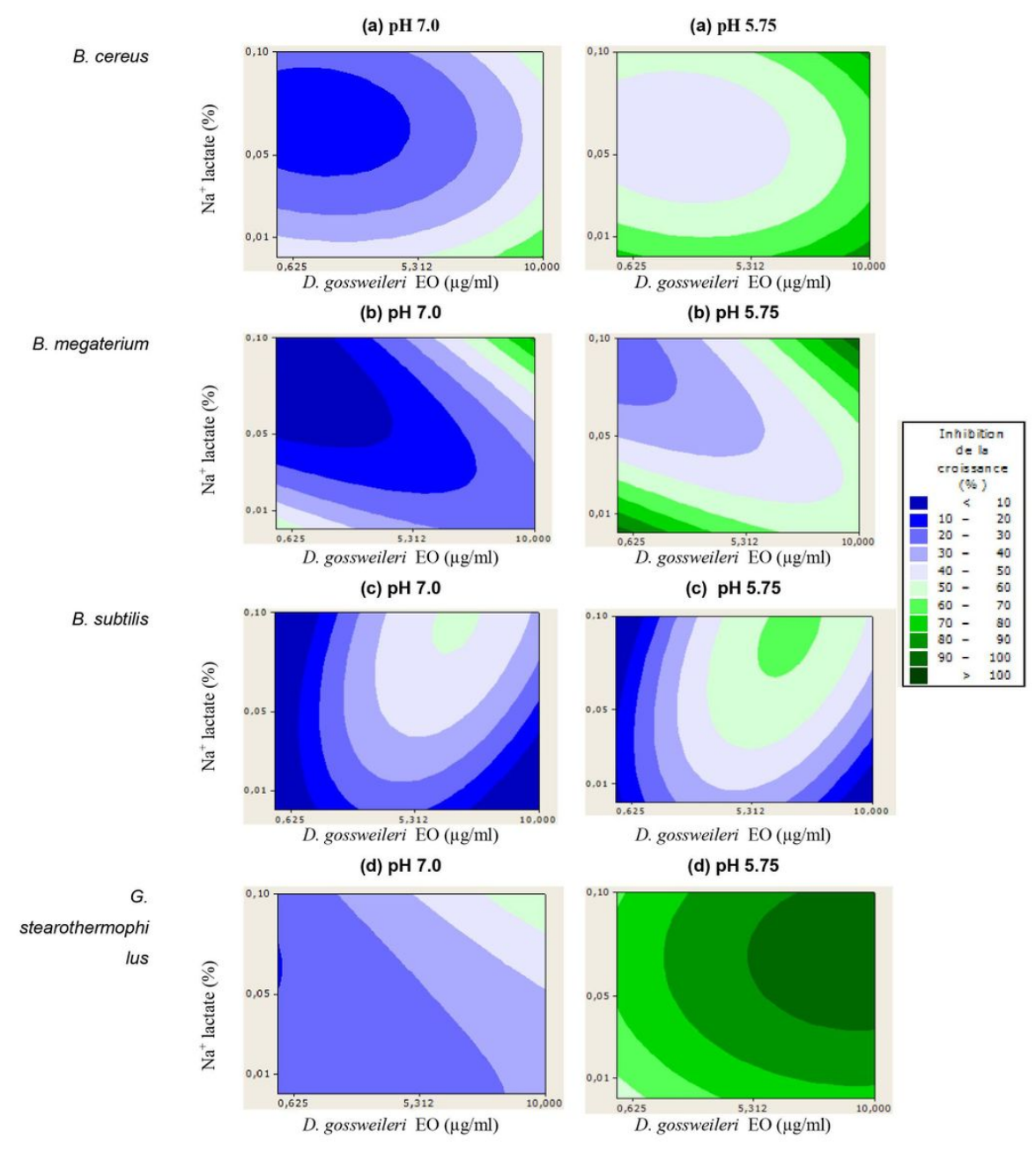

\section{Figure 2}

Contours plots of the percentages inhibition of germination and spores growth at different concentrations of $D$. gossweileri $\mathrm{EO}$, Na ${ }^{+}$lactate and pH; with: (a) = B. cereus; $\mathbf{( b )}=B$. megaterium; $(\mathbf{c})=B$. subtilis; $(\mathbf{d})=$ G. stearothermophilus 


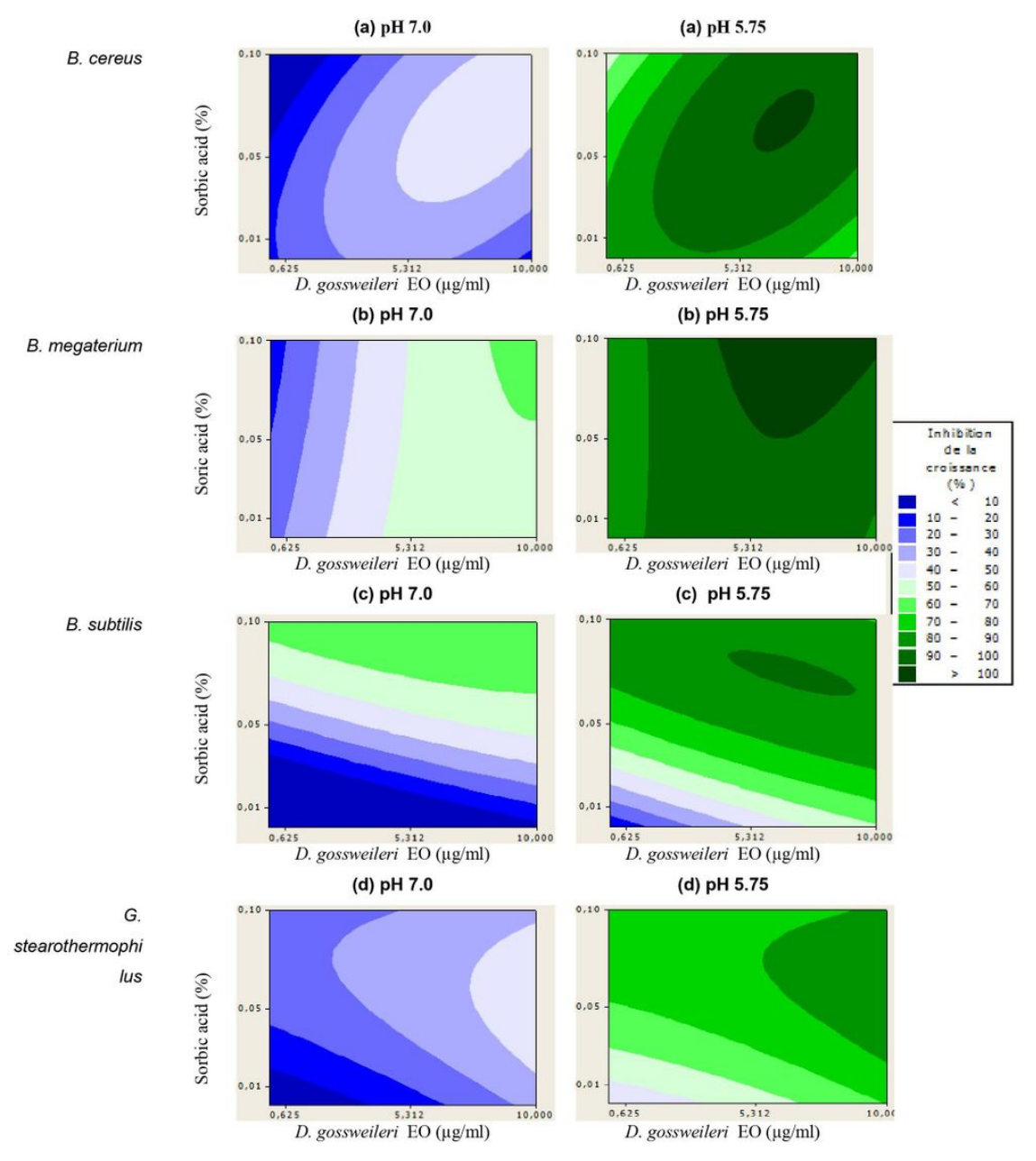

\section{Figure 3}

Contours plots of the percentages inhibition of germination and spores growth at different concentrations of $D$. gossweileri EO, Sorbic acid and pH; with (a) = B. cereus; $(\mathbf{b})=$ B. megaterium; $\mathbf{( c )}=$ B. subtilis; $(\mathbf{d})=$ G. stearothermophilus 